\title{
Glutamine uptake and utilization by preimplantation mouse embryos in CZB medium
}

\author{
C. L. Chatot, R. J. Tasca* and C. A. Ziomek \\ Worcester Foundation of Experimental Biology, Shrewsbury, MA 01545, USA; and \\ * National Institute of Child Health and Human Development, National Institutes of Health, \\ Bethesda, MD 20892, USA
}

\begin{abstract}
Summary. At least $71 \%$ of CF1 $\times$ B6SJLF1/J embryos developed from the 1-cell stage to the blastocyst stage in an optimum glutamine concentration of $1 \mathrm{~mm}$, as long as glucose was present after the first $48 \mathrm{~h}$ of culture. Blastocysts raised under these conditions had significantly more cells than did blastocysts raised in CZB medium alone (glutamine present, glucose absent). Embryos raised in vivo accumulated 170-200 fmol glutamine/embryo/h at the unfertilized egg and 1 -cell stages with a decline to $145 \mathrm{fmol} /$ embryo/h at the 2-cell stage, followed by sharp increases to 400 and $850 \mathrm{fmol} / \mathrm{embryo} / \mathrm{h}$ at the 8-cell and blastocyst stages. The presence or absence of glucose in the labelling medium had no effect on glutamine uptake by these embryos. Embryos raised in vitro accumulated 2-3 times more glutamine at stages comparable to those of embryos raised in vivo. In all cases in which 1-cell to blastocyst development in vitro was successful, glucose was present in the culture medium and the incremental uptake of glutamine between the 8-cell stage and the blastocyst stage was approximately 2 -fold. This was also the increment for in-vivo raised embryos. When glucose was not present after the first $48 \mathrm{~h}$, the 8 -cell to blastocyst glutamine increment was not significant, and development into blastocysts was reduced. The results also show that glutamine can be used as an energy source for the generation of $\mathrm{CO}_{2}$ through the TCA cycle by all stages of preimplantation mouse development, whether raised in vivo or in vitro from the 1-cell stage. Two-cell embryos raised in vivo converted as much as $70 \%$ of the glutamine uptake into $\mathrm{CO}_{2}$, consistent with an important role for glutamine in the very earliest stages of preimplantation development. Cultured blastocysts appeared to convert less glutamine and the presence of glucose in the culture medium seemed to inhibit this conversion.
\end{abstract}

Keywords: mouse embryo; glutamine; uptake; energy substrate

\section{Introduction}

Successful culture of 1-cell mouse embryos beyond the 2-cell stage has been reported to be a function of mouse strain (Whitten \& Biggers, 1968; Kaufman \& Sachs, 1976; Abramczuk et al., 1977), culture medium (Biggers et al., 1967; Whittingham \& Biggers, 1967; Cross \& Brinster, 1973; Abramczuk et al., 1977; Loutradis et al., 1987) and culture environment (Quinn \& Harlow, 1978). Chatot et al. (1989) have shown that the use of CZB medium that contains glutamine and EDTA, but not glucose, for the culture of CF $1 \times \mathrm{B} 6 \mathrm{SJLF} 1 / \mathrm{J} 1$-cell embryos (which block at the 2-cell stage in vitro in most media) allows the development of $83 \%$ of these embryos beyond the 2-cell stage. At least $50 \%$ will develop to the blastocyst stage in CZB medium, provided that glucose is added to the culture at $48 \mathrm{~h}$. This medium has been used to culture 1-cell embryos from a variety of different 
strains of mice (Chatot et al., 1990) with only minor adjustment to the timing of the glucose addition required by the embryos for optimum development to the blastocyst stage.

Glutamine has been implicated as an important amino acid in the maturation of hamster oocytes (Gwatkin \& Haidri, 1973), in the development of rabbit embryos (Bae \& Foote, 1975), in the development of hamster embryos beyond the 2-, 4- and 8-cell culture blocks (Bavister et al., 1983; Carney \& Bavister, 1987; Schini \& Bavister, 1988), in the development of random-bred mouse zygotes beyond the 2-cell stage in culture (Chatot et al., 1989, 1990) and in the in-vitro development of pig embryos from the 1-2-cell stage to the blastocyst stage (Petters et al., 1990).

Glutamine has been shown in a variety of cultured cell lines (Eagle et al., 1955; Zielke et al., 1976, 1984; Reitzer et al., 1979; Brand, 1985; Lanks, 1987) and in bovine blastocysts (Rieger \& Guay, 1988) to be utilized as an energy substrate in place of glucose via its oxidation to $\mathrm{CO}_{2}$ through the TCA cycle. A reciprocal relationship between the utilization of glutamine and glucose has been demonstrated in human diploid fibroblasts (Zielke et al., 1984). In addition to its role as a potential energy substrate, the conversion of glutamine to glutamate and subsequently to $\alpha$ ketoglutarate is central to a series of reactions in intermediary metabolism (Stryer, 1988), including the synthesis of NAD, heteropolysaccharides, glycoproteins, and amino acids, as well as feeding ammonia into the urea cycle. Glutamine is also required for the synthesis of purine and pyrimidine bases necessary for nucleic acid synthesis (Salzman et al., 1958; Nomura \& Rubin, 1988).

The present study expands the observations on glutamine in the preimplantation mouse embryo: (1) to determine optimum concentrations of glutamine for embryo development in vitro; (2) to determine whether pyrrolglutamic acid, a degradation product of glutamine (Blomback, 1967), is toxic to embryos; (3) to characterize and compare the uptake of glutamine in embryos isolated from in vivo at various stages with that of embryos cultured in CZB medium in the presence and absence of glucose, and (4) to determine whether glutamine is metabolized through the TCA cycle to $\mathrm{CO}_{2}$ in embryos raised in vivo as compared with those cultured in vitro.

\section{Materials and Methods}

Embryo collection for culture. CF1 female mice (Harlan Sprague-Dawley, Colony 202, Indianapolis, IN, USA) were superovulated with intraperitoneal injections of 10 i.u. PMSG (Calbiochem, La Jolla, CA, USA) followed $48 \mathrm{~h}$ later by 5 i.u. hCG (Organon, W. Orange, NJ, USA). CF1 females were mated overnight with B6SJLF1/J males (Jackson Laboratories, Bar Harbor, ME, USA). Embryos were flushed from excised oviducts at 25-27 h after hCG into Hanks' balanced salt solution with $4 \mathrm{mg}$ bovine serum albumin/ml (Cat. *0140, Armour Pharmaceutical Co., Kankakee, IL, USA) (HBSS + BSA), treated briefly (if necessary) with hyaluronidase [ $300 \mathrm{units} / \mathrm{ml}$ in phosphate-buffered saline (PBS) containing $1 \%$ polyvinylpyrrolidone (Sigma Chemical Co., St Louis, MO, USA)] to remove cumulus cells, washed 3 times in HBSS + BSA and placed in holding drops of CZB medium as previously described (Chatot et al., 1989), Embryos from each mouse were kept in separate 50- $\mu$ l holding drops of CZB medium until adequate numbers of embryos were collected and then randomly distributed in fresh holding drops across all samples in each experiment. All manipulations were performed in a darkened room (Schumacher \& Fischer, 1988) and all solutions, dishes and instruments were maintained at $37^{\circ} \mathrm{C}$ before use.

Culture media. Embryos were cultured in CZB medium (Chatot et al., 1989) which contains $5 \mathrm{mg} \mathrm{BSA} / \mathrm{ml}, 1 \mathrm{~mm}-$ glutamine and lacks glucose. CZB medium was prepared on the basis of weight using sterile endotoxin-free tissue culture grade water (Cat. * W3500, Sigma) or water from a Nanopure II water purification system (Nanopure, Sybron/Barnstead, Boston, MA, USA) as previously described (Chatot et al., 1989). Glutamine was added immediately before use from a freshly prepared $100 \mathrm{~mm}$ stock to give a final concentration of $1 \mathrm{~mm}$. Medium was stored gassed with $5 \% \mathrm{CO}_{2} / 5 \% \mathrm{O}_{2} / 90 \% \mathrm{~N}_{2}$ at $4{ }^{\circ} \mathrm{C}$ and was prepared every 2 weeks.

Culture procedures. Media were pipetted in $50-\mu l$ drops onto Falcon $35 \mathrm{~mm}$ Petri dishes (Falcon Cat. * 1008 , Beckton Dickinson, Lincoln Park, NJ, USA), overlaid with medium-washed Fisher 121 paraffin oil, gassed in a sealed culture chamber (Billips Rothenberg, Del Mar, CA, USA) with $5 \% \mathrm{CO}_{2} / 5 \% \mathrm{O}_{2} / 90 \% \mathrm{~N}_{2}$ and equilibrated at $37^{\circ} \mathrm{C}$ for 4-5 h before use (Chatot et al., 1989). Randomly distributed l-cell embryos were removed from the holding dishes, washed through a drop of fresh medium and placed into a final culture drop: 25 embryos were cultured in a $50 \mu l$ drop. Cultures were placed in a sealed culture chamber, gassed as described above and incubated at $37^{\circ} \mathrm{C}$ for $96 \mathrm{~h}$. Cultures that required an exposure to glucose were removed from the chamber at $48 \mathrm{~h}$ of culture, $2.5 \mu \mathrm{l}$ of a sterile $100 \mathrm{mg}$ glucose/ml tissue culture grade $\mathrm{H}_{2} \mathrm{O}$ stock were injected directly into the culture drop and cultures were returned to the chamber for continued incubation. In some cases, pyrrolglutamic acid (PGA) was added to the medium at the $57 \mathrm{AM}$ 
start of culture to give a final concentration of $1 \mathrm{~mm}$ in addition to the glutamine already present. Embryos were scored for developmental stage and abnormalities at 72 and $96 \mathrm{~h}$ of culture and cultures were terminated at $96 \mathrm{~h}$. Embryos were fixed in 4\% paraformaldehyde, washed into PBS and stained with Hoechst $33258(10 \mu \mathrm{g} / \mathrm{ml}$ in HBSS + BSA, Cat. * B2883, Sigma) to label the nuclei fluorescently. Nuclei were counted on a Nikon Diaphot inverted phasecontrast microscope with fluorescence attachments under u.v. illumination. The average numbers of nuclei per morula and per blastocyst were calculated.

To control for variation between litters, embryos from each animal were randomly distributed across all samples in a given experiment. Each experimental protocol represents between 3 and 8 repetitions performed on different days and by different individuals. For all experiments, a complete set of samples was run simultaneously. Statistical analysis of experiments was performed with an NCSS software package (Number Crunching Statistical System, NCSS, Kayville, UT, USA) using a standard arcsin transformation (Sokal \& Rohlf, 1981) of the data and Student's $t$ test. Analysis of morula and blastocyst cell numbers were performed on non-transformed nuclear counts using Student's $t$ test.

Uptake of radioactive glutamine. As controls, embryos were isolated as unfertilized eggs or at $25 \mathrm{~h}$ (1-cells), $49 \mathrm{~h}$ (2cells), $73 \mathrm{~h}$ (8-16-cells) and $97 \mathrm{~h}$ (blastocysts) after hCG injection and mating. Embryos were flushed in HBSS + BSA, treated with hyaluronidase to remove cumulus cells (if necessary), washed through three drops of HBSS + BSA to remove debris and placed in a holding drop of CZB medium. Embryos cultured as described above in (1) CZB medium, (2) CZB medium with $5.5 \mathrm{~mm}$-glucose or (3) CZB medium with a 48-h (Day-3) glucose injection, were removed from culture at $24 \mathrm{~h}$ ( 2 -cells), $48 \mathrm{~h} \mathrm{(4-8-cells),} 72 \mathrm{~h}$ (8-cells to morulae) and $96 \mathrm{~h}$ (blastocysts) and washed into a fresh holding drop of $\mathrm{CZB}$ medium with or without glucose as required. For labelling, all embryos were washed through a $50 \mu \mathrm{l}$ drop of $\mathrm{CZB}$ medium with or without glucose and $1 \mathrm{~mm}$ unlabelled glutamine and $12 \cdot 5 \mu \mathrm{Ci}\left[{ }^{3} \mathrm{H}\right]$ glutamine (NEN, DuPont, Boston, MA, USA; Cat. * NET-551; sp. act. 43.8-58.4 Ci/mmol), into another identical drop for labelling. For each experiment, $\left[{ }^{3} \mathrm{H}\right]$ glutamine was evaporated to dryness under vacuum and resuspended in the appropriate volume of CZB medium. For glutamine titration experiments, labelling medium contained the same amount of radioactive glutamine but different amounts of unlabelled glutamine as indicated (Fig. 1). In a 50- $\mu$ l culture drop, 100 embryos were labelled. Culture dishes were placed into a sealed culture chamber, gassed with $5 \% \mathrm{CO}_{2} / 5 \%$ $\mathrm{O}_{2} / 90 \% \mathrm{~N}_{2}$ and then incubated at $37^{\circ} \mathrm{C}$ for $30 \mathrm{~min}$. Embryos were removed in groups of 25 , washed rapidly through 3 drops of CZB medium without radioactivity and frozen in $1-2 \mu l$ medium in $1.5 \mathrm{ml}$ microcentrifuge tubes at $-20^{\circ} \mathrm{C}$. For processing, samples were thawed, $10 \mu \mathrm{l}$ water added and embryos were freeze-thawed 3 times. Embryo lysates were precipitated with trichloroacetic acid (TCA) to generate acid-soluble and acid-precipitable fractions (Tasca \& Hillman, 1970; Brinster, 1971; Borland \& Tasca, 1974) that were then analysed by scintillation counting in Ecolume scintillation fluor (ICN Biomedicals, Inc., Irvine, CA, USA). Average c.p.m. per sample (determined in a Packard Tricarb 460 scintillation counter) were converted to glutamine uptake in fmol per embryo per $\mathrm{h}$ based on the specific activity of the radiolabelled glutamine and the proportion of non-radioactive to radioactive glutamine in the medium. For each experiment, 2-10 replicates were performed and significant differences were determined by Student's $t$ test.

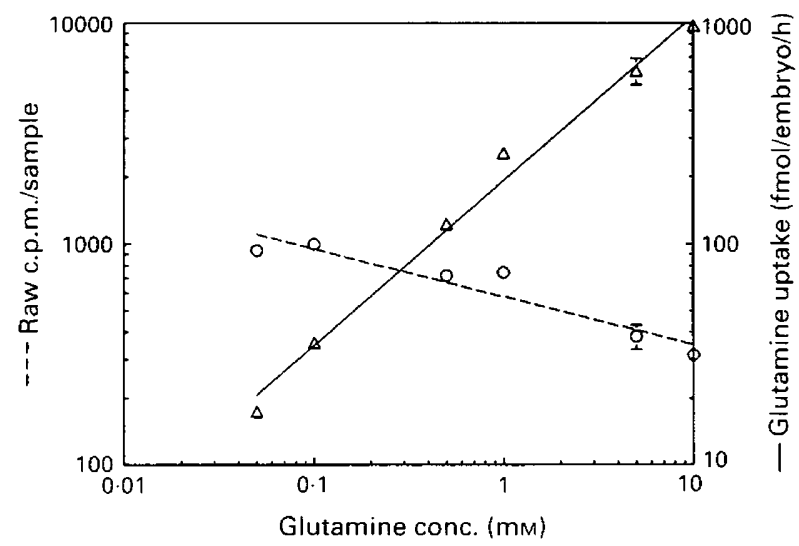

Fig. 1. Concentration curve for $\left[{ }^{3} \mathrm{H}\right]$ glutamine uptake by unlabelled glutamine. One-cell $\mathrm{CF} 1 \times \mathrm{B} 6 \mathrm{SJLF} 1 / \mathrm{J}$ embryos were incubated in CZB medium containing $12.5 \mu \mathrm{Ci}\left[{ }^{3} \mathrm{H}\right] \mathrm{gluta}-$ mine and $0.05,0.1,0.5,1.0,5.0$ or $10.0 \mathrm{~mm}$ non-radioactive glutamine for $30 \mathrm{~min}$. Embryos were processed as described in 'Methods'. Data represent averages of 4 replicates for each point \pm s.e.m.

Efflux of radioactive glutamine. One-cell embryos were treated with hyaluronidase, washed 3 times in HBSS + BSA and placed in a holding drop of CZB medium with $1 \mathrm{mM}$-glutamine. Embryos were washed through a $50 \mu \mathrm{l}$ drop of $\mathrm{CZB}$ with $1 \mathrm{~mm}$-glutamine and $5 \mu \mathrm{Ci}\left[{ }^{3} \mathrm{H}\right]$ glutamine into an identical labelling drop. Each $50 \mu \mathrm{l}$ labelling drop 
contained 100 embryos. Culture dishes were placed in a sealed culture chamber, gassed with $5 \% \mathrm{CO}_{2} / 5 \% \mathrm{O}_{2} / 90 \% \mathrm{~N}_{2}$ and incubated at $37^{\circ} \mathrm{C}$ for $1 \mathrm{~h}$. Groups of 25 embryos were removed from their labelling drops, washed rapidly through 3 drops of CZB medium containing $0,0.001,0.01,0.1$ or $1.0 \mathrm{~mm}$-glutamine and placed in $50 \mu \mathrm{l}$ drops of CZB medium containing these same amounts of glutamine. A single 25 -embryo sample was frozen immediately after washing to serve as a no-efflux control. Culture dishes were returned to the sealed, gassed culture chamber and incubated at $37^{\circ} \mathrm{C}$ for $1 \mathrm{~h}$. Embryos were removed from their efflux drops and frozen immediately in $1 \mu \mathrm{l}$ efflux medium. Samples were precipitated with TCA as previously described. Data represent the average of 4 replicates. Significant differences between the effects of different concentrations of glutamine during efflux were evaluated by Student's $t$ test.

Generation of $\mathrm{CO}_{2}$ from ${ }^{14} \mathrm{C} / g$ lutamine. As described for glutamine uptake experiments, embryos were flushed from the oviducts or uteri at 24-h intervals for in-vivo raised samples and embryos were removed from culture at $24-\mathrm{h}$ intervals from Day 2 through Day 5 of culture. Isolated embryos were washed through 3 drops of glutamine-free Hepes-buffered CZB medium ( $\mathrm{pH} 7 \cdot 0$ ). This medium differed from regular CZB medium (Chatot et al., 1989) in that the sodium bicarbonate was replaced with $25 \mathrm{~mm}$-Hepes and the $\mathrm{pH}$ was adjusted to 7.0 rather than 7.4 . Labelling and $\mathrm{CO}_{2}$ generation were performed according to the hanging-drop procedure of O'Failon \& Wright (1986). Three embryos of each stage raised in vivo and in vitro were pipetted in $1.5 \mu$ glutamine-free Hepes-buffered CZB medium into $1.5 \mu l$ Hepes-buffered CZB medium with $2 \mathrm{mM}-\left[{ }^{14} \mathrm{C}\right]$ glutamine (sp. act. $271 \mathrm{mCi} / \mathrm{mmol}$; Cat. ${ }^{*} \mathrm{NEC}-45 \mathrm{l}$; NEN, DuPont) on the inside of the cap of a $1.5-\mathrm{ml}$ microcentrifuge tube. Final conditions were 3 embryos in $3 \mu \mathrm{l}$ Hepesbuffered CZB with I mM- $\left[{ }^{14} \mathrm{C}\right]$ glutamine. Microcentrifuge tube lids were inverted and tightly closed onto microcentrifuge tubes containing $1.5 \mathrm{ml} 0 \cdot 1 \mathrm{M}-\mathrm{NaOH}$ which acts as a trap for the $\mathrm{CO}_{2}$ that is generated. Microcentrifuge tubes were incubated at $37^{\circ} \mathrm{C}$ for $4 \mathrm{~h}$. Lids were then removed and the tubes were inverted into a 20 -ml scintillation vial containing $10 \mathrm{ml}$ Ecolume scintillation fluor. Radioactivity generated as $\mathrm{CO}_{2}$ was counted in a Packard Tri-carb 460 scintillation counter. For each embryo stage tested, 9-10 replicates were performed. Controls included radioactive medium without embryos and embryos without radioactive medium. Raw c.p.m. values were corrected for background as determined by controls for each experiment and converted to fmol glutamine utilized per embryo per $\mathrm{h}$ to generate $\mathrm{CO}_{2}$ based on the specific activity of the glutamine. Statistically significant differences were evaluated by Student's $t$ test.

\section{Results}

Embryo culture

Preliminary experiments demonstrated that CZB medium containing 1 mM-glutamine compared with 2 or 5 mM-glutamine was optimal for development of 1-cell CF $1 \times$ B6SJLF1/J embryos to the blastocyst stage (C. L. Chatot \& C. A. Ziomek, unpublished data). However, the possibility that $1 \mathrm{~mm}$-glutamine might be suboptimal in comparison with lower glutamine concentrations was not tested. Therefore, the ability of CZB medium to support development of 1-cell $\mathrm{CF} 1 \times \mathrm{B} 6 \mathrm{SJLF} 1 / \mathrm{J}$ embryos was assessed, both with and without a Day-3 glucose injection, using $1,0.5$ and $0.1 \mathrm{~mm}$-glutamine. One-cell embryos cultured in CZB medium with $1 \mathrm{~mm}$-glutamine and a Day-3 glucose injection developed better than any other variation (Table 1), with $71 \%$ reaching the blastocyst stage. The addition of only $0.1 \mathrm{~mm}$-glutamine with a Day-3 glucose injection slowed the development of embryos to the morula stage on Day 4, as well as to the blastocyst stage on Day 5. In the absence of a Day-3 glucose injection, there was no statistically significant improvement in development to the blastocyst stage by reducing the glutamine concentration. The average cell number of the blastocysts obtained in CZB medium with $1 \mathrm{~mm}$-glutamine and a Day-3 glucose injection was $34.33 \pm 1 \cdot 16$ cells per embryo $(n=69)$. This was not significantly larger than that observed for blastocysts obtained by the other glutamine treatments in the presence of glucose on Day $3[32.35 \pm 1.39(n=55)$ with $0.5 \mathrm{~mm} ; 32.32 \pm 1.56(n=37)$ with $0.01 \mathrm{~mm}]$. However, blastocysts obtained in the absence of a Day-3 glucose injection $[21.43 \pm 1.36(n=21)$ with $1 \mathrm{~mm}$; $25.03 \pm 1.41(n=39)$ with $0.05 \mathrm{~mm}$; and $22.29 \pm 1.35(n=34)$ with $0.1 \mathrm{~mm}$ ] had significantly fewer cells than those in the Day-3 glucose injection group; $(P<0.001$ by Student's $t$ test for all comparisons).

To determine whether glutamine breakdown to pyrrolglutamic acid by Days $3-5$ of culture was toxic to the embryos, thus necessitating a Day-3 glucose injection to allow development to proceed to the blastocyst stage, PGA was added to cultures of 1-cell embryos at a final concentration of $1 \mathrm{~mm}$ in addition to the $1 \mathrm{~mm}$-glutamine which was present in the culture medium. Compared with 
Table 1. Titration of optimum glutamine concentration for 1-cell embryo development

\begin{tabular}{|c|c|c|c|c|c|c|c|c|c|c|c|c|c|}
\hline \multirow[b]{2}{*}{ Glutamine } & \multicolumn{6}{|c|}{ Day 4} & \multicolumn{7}{|c|}{ Day 5} \\
\hline & Total & $\% A b n$ & $\% 2 \mathrm{C}$ & $\% 3-8 C$ & $\% \mathbf{M}$ & $\% \mathrm{Bl}$ & Total & $\% A b n$ & $\% 2 \mathrm{C}$ & $\% 3-8 \mathrm{C}$ & $\% \mathrm{M}$ & $\% B !$ & $\% M+B l$ \\
\hline \multicolumn{14}{|c|}{ Day-3 glucose injection } \\
\hline $1.0 \mathrm{~mm}$ & 100 & 4 & 0 & 1 & 89 & 5 & 100 & 28 & 0 & 0 & 1 & 71 & 72 \\
\hline $0.5 \mathrm{~mm}$ & 100 & 3 & 2 & 9 & 82 & 4 & 101 & 30 & 0 & 6 & 8 & 56 & 64 \\
\hline $0.1 \mathrm{~mm}$ & 100 & 12 & 2 & 19 & 65 & 2 & 100 & 50 & 1 & 3 & 10 & $37^{a}$ & 47 \\
\hline \multicolumn{14}{|c|}{ No Day-3 glucose injection } \\
\hline $1.0 \mathrm{~mm}$ & 149 & 7 & 0 & 4 & 88 & 1 & 148 & 78 & 0 & 0 & 6 & $16^{\mathrm{a}}$ & 22 \\
\hline $0.5 \mathrm{~mm}$ & 148 & 3 & 0 & 7 & 89 & 1 & 148 & 62 & 0 & 2 & 8 & $28^{\mathrm{a}}$ & 36 \\
\hline $0.1 \mathrm{~mm}$ & 149 & 5 & 1 & 11 & 83 & 0 & 149 & 64 & 1 & 1 & 9 & $24^{a}$ & 34 \\
\hline
\end{tabular}

Abbreviations: Total $=$ total number of embryos; $\mathrm{Abn}=$ abnormal; $2 \mathrm{C}=2$-cell; $3-8 \mathrm{C}=3-8$-cell; $\mathrm{M}=$ morula; $\mathrm{Bl}=$ blastocyst .

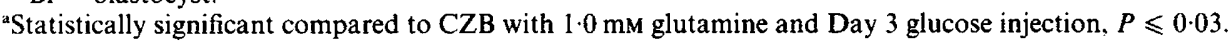

CZB controls, PGA in the culture medium with a Day-3 glucose injection did not significantly inhibit the development of 1-cell embryos to the morula [99\% - PGA vs $91 \%+$ PGA; Day 4] or blastocyst stage [78\% - PGA vs 63\% + PGA; Day 5]. The transition from morula to blastocyst appeared to be slowed by the PGA [3\% morula - PGA vs 19\% morula + PGA, Day 5] but this was not statistically significant. In the absence of Day-3 glucose injection, PGA did not inhibit the development of embryos to the morula stage [91\% for - PGA and + PGA, Day 4] and prevented the degeneration of embryos to the abnormal category between Days 4 and 5 (67\% abnormal) compared with the CZB controls ( $83 \%$ abnormal), although the percentage development to the blastocyst stage (13\%) was not significantly different from controls $(10 \%)$ on Day 5 . Development in the presence of a Day-3 glucose injection was significantly better than without a Day-3 glucose injection in all cases $(P<0.03$ by Student's $t$ test). Nuclear counts on blastocysts which developed in the presence of a Day-3 glucose injection were not significantly different with or without PGA [34.33 $\pm 0.85(n=9)$ with CZB medium control; $34.44 \pm 1 \cdot 38(n=9)$ with PGA].

\section{Glutamine uptake}

Preliminary experiments with 1 -cell embryos labelled with $\left[{ }^{3} \mathrm{H}\right]$ glutamine suggested that embryos took up glutamine linearly for at least $1 \mathrm{~h}$ (data not shown). To determine the effect of non-radioactive glutamine in the labelling medium, 1-cell embryos were incubated in the presence of equal amounts of $\left[{ }^{3} \mathrm{H}\right]$ glutamine and increasing amounts of unlabelled glutamine $(0 \cdot 05,0 \cdot 1,0 \cdot 5$, $1 \cdot 0,5 \cdot 0$ and $10 \cdot 0 \mathrm{~mm}$ ) (Fig. 1). Uptake of $\left[{ }^{3} \mathrm{H}\right]$ glutamine decreased linearly with the addition of nonradioactive glutamine ( $r=0.95$ by linear regression) from $934.75 \pm 36.60$ c.p.m. at $0.05 \mathrm{~mm}$ unlabelled glutamine to $315 \cdot 00 \pm 2 \cdot 35$ c.p.m. at $10 \mathrm{~mm}$ unlabelled glutamine. This converts to a linear increase in overall glutamine uptake, assuming that the radiolabelled glutamine is taken up at the same rate as unlabelled glutamine, from $17.42 \pm 0.71 \mathrm{fmol} / \mathrm{embryo} / \mathrm{h}$ at $0.05 \mathrm{~mm}$ unlabelled glutamine to $972.03 \pm 8.3 \mathrm{fmol} / \mathrm{embryo} / \mathrm{h}$ at $10 \mathrm{~mm}$ glutamine ( $r=0.99$ by linear regression). After TCA precipitation, $92-98 \%$ of all counts were in the TCA-soluble fraction.

Glutamine uptake was then determined for embryos isolated from in vivo at unfertilized egg, 1cell, 2-cell, 8-cell to early morula, and blastocyst stages (Table 2). Uptake was measured in the absence and presence of glucose in the CZB medium. Uptake of glutamine to CZB medium declined between the 1-cell and the 2-cell stages, and then increased to the blastocyst stage. The addition of glucose to the labelling medium had a significant effect only at the blastocyst stage. As with the glutamine titration data, 96-98\% of glutamine uptake was found in the TCA-soluble rather than in TCA-precipitable material. 
Table 2. Glutamine uptake ( $\mathrm{fmol} / \mathrm{embryo} / \mathrm{h}$ ) in embryos isolated from CFl females at the indicated stages or from cultures on the indicated days and labelled with $\left[{ }^{3} \mathrm{H}\right]$ glutamine in CZB medium or CZB medium with glucose both containing non-radioactive $1 \mathrm{~mm}$-glutamine for $30 \mathrm{~min}$ at $37^{\circ} \mathrm{C}$

\begin{tabular}{|c|c|c|c|c|c|}
\hline \multicolumn{3}{|c|}{ In vivo } & \multicolumn{3}{|r|}{ In vitro } \\
\hline $\begin{array}{l}\text { Embryo } \\
\text { stage }\end{array}$ & $\mathrm{N}$ & $\begin{array}{l}\text { Total uptake } \\
\text { (\% TCA ppt) }\end{array}$ & $\begin{array}{l}\text { Day of } \\
\text { cuiture }\end{array}$ & $\mathrm{N}$ & $\begin{array}{l}\text { Total uptake } \\
\text { (\% TCA ppt) }\end{array}$ \\
\hline \multicolumn{3}{|l|}{$C Z B$} & \multicolumn{3}{|l|}{$C Z B$} \\
\hline Unfertilized egg & 4 & $203 \cdot 95 \pm 62 \cdot 38(3 \cdot 7)$ & 2 & 4 & $305.78 \pm 8.92(0.84)^{\mathrm{e}}$ \\
\hline 1 -cell & 4 & $172.83 \pm 2.84(4.2)^{a}$ & 3 & 4 & $776.87 \pm 13.87(0.47)^{e . f . \mathrm{b}}$ \\
\hline 2-cell & 4 & $145.85 \pm 3.67(3.6)^{\mathrm{a} . \mathrm{b}}$ & 4 & 4 & $1066.60 \pm 33.93(0 \cdot 22)^{f \cdot g . i}$ \\
\hline 8-cell-morula & 4 & $394.50 \pm 7 \cdot 19(1 \cdot 7)^{\mathbf{b} \cdot \mathbf{c}}$ & 5 & 4 & $1235.00 \pm 37.73(0.90)^{8 . j}$ \\
\hline \multirow[t]{2}{*}{ Blastocyst } & 4 & $858.75 \pm 9.92(2.4)^{\text {c.d }}$ & & & \\
\hline & & & \multicolumn{3}{|c|}{$C Z B+$ glucose } \\
\hline$C Z B+$ glucose & & & 2 & 2 & $308.77 \pm 3.67(0.48)$ \\
\hline Unfertilized egg & 3 & $191.28 \pm 3.41(4.5)$ & 3 & 2 & $673.68 \pm 21.60(0.81)^{h}$ \\
\hline 1 -cell & 4 & $174.03 \pm 6.76(3.5)$ & 4 & 2 & $1274.31 \pm 56.11(0.30)^{\mathrm{i}}$ \\
\hline 2-cell & 4 & $117.85 \pm 14.05(2.9)$ & 5 & 2 & $2703.46 \pm 141 \cdot 38(0.68)^{\mathbf{j}}$ \\
\hline 8-cell-morula & 4 & $402 \cdot 11 \pm 17 \cdot 18(1 \cdot 2)$ & & & \\
\hline \multirow[t]{3}{*}{ Blastocyst } & 4 & $767.25 \pm 9.05(2.4)^{\mathrm{d}}$ & \multicolumn{3}{|c|}{$C Z B \rightarrow$ Day $3+$ glucose } \\
\hline & & & 4 & 4 & $1118.24 \pm 46.65(0.31)$ \\
\hline & & & 5 & 4 & $2047.49 \pm 97 \cdot 10(0 \cdot 68)^{\mathbf{j}}$ \\
\hline
\end{tabular}

Values are mean \pm s.e.m. for the no. of replicates $(N)$ indicated; each contained 20-25 embryos. CZB $\rightarrow$ Day $3+$ glucose, embryos were grown in CZB medium for Days 1 and 2 of culture, on Day 3 at $48 \mathrm{~h}$ glucose was injected into the culture as described in 'Methods'.

a,b,c,d,e,f,g,h,i,j $L_{i k e}$ pairs are significantly different from each other at $P \leqslant 0.001(\mathrm{a}, \mathrm{b}, \mathrm{c}, \mathrm{d}), P \leqslant 0.02(\mathrm{i}), \mathrm{P} \leqslant 0.01(\mathrm{f}, \mathrm{g}, \mathrm{h})$ and $P \leqslant 0.003(\mathrm{e}, \mathrm{j})$.

Uptake of $\left[{ }^{3} \mathrm{H}\right]$ glutamine was also measured in embryos cultured from the 1-cell stage in CZB medium in the presence and absence of glucose from the start of culture as well as with a Day-3 glucose injection (Table 2). Embryos showed significant increases in glutamine uptake between Days 2 and 3, 3 and 4 and 4 and 5 in all cases. However, in CZB medium without glucose signifcantly less glutamine was taken up by embryos which developed to the blastocyst stage under these conditions than by blastocysts which developed in the presence of glucose from the start of culture or with a Day-3 injection of glucose. Blastocysts cultured in the presence of glucose increased their rate of glutamine uptake by about 2-fold over the 8-cell stage. Those raised without glucose in the medium hardly increased uptake at all between the 8-cell and blastocyst stages. The few blastocysts which developed in CZB medium lacking glucose were generally smaller and less healthy than those which developed in the presence of glucose. Glucose did not affect the fraction of glutamine that was TCA-precipitable: $>99 \%$ glutamine was found in the TCA-soluble fraction of cultured embryos.

When uptake of glutamine in cultured embryos (Table 2) was compared with that of embryos isolated from in vivo (Table 2) at the same approximate stage, i.e. 2-cells in both cases, 4-cells in vitro compared with 2-cells or 8-cells in vivo, 8-cell to morula in vitro compared with 8-cells in vivo and blastocysts in both cases, regardless of stage, there was a significantly higher rate of glutamine uptake in cultured embryos than in in-vivo raised embryos $(P \leqslant 0.001$ for total and TCA-soluble glutamine). However, less glutamine was found in the TCA-precipitable fraction in in-vitro raised embryos $(P \leqslant 0.03)$. The percentage of total glutamine that was found in TCA-precipitable counts in vitro was $5-10 \%$ of that in vivo (Table 2 ). This was largely a function of the overall increase in glutamine uptake exhibited by embryos in culture rather than a large decrease in the absolute amount of glutamine in TCA-precipitable material.

In another series of experiments, glutamine uptake by embryos raised both in vivo and in vitro was assessed in CZB medium with and without glucose in the presence of only $\left[{ }^{3} \mathrm{H}\right]$ glutamine $(12.5 \mu \mathrm{Ci}, 0.214 \mathrm{nmol})$ without additional unlabelled glutamine. In CZB medium, glutamine uptake 
for embryos raised in vivo was $3.44 \pm 0.26$ (1-cell), $5 \cdot 13 \pm 0.59$ (2-cell), 17.47 $\pm 1 \cdot 19$ (8-cell) and $51 \cdot 72 \pm 5 \cdot 23$ (blastocyst) fmol/embryo/h. The addition of glucose to the labelling medium did not affect the uptake of glutamine by in-vivo raised embryos (data not shown). Embryos cultured in CZB medium with glutamine before labelling in CZB medium without unlabelled glutamine accumulated similar amounts of glutamine compared with in-vivo raised embryos at the 2-cell, 4cell and 8-cell-morula stages $(2.52 \pm 0.39,15.00 \pm 1.22$ and $18.79 \pm 2.09 \mathrm{fmol} / \mathrm{embryo} / \mathrm{h}$ respectively). However, at the blastocyst stage, uptake declined to $13.19 \pm 1.95 \mathrm{fmol} / \mathrm{embryo} / \mathrm{h}$. In cultured embryos, the addition of glucose to the culture medium from the start of culture or at Day 3 and its inclusion in the labelling medium did not affect glutamine uptake at the 2-, 4- or 8-cell stages (data not shown) but increased uptake at the blastocyst stage to $32.09 \pm 6.50$ (CZB + glucose) and $31 \cdot 18 \pm 1.95($ CZB + Day-3 glucose injection) $\mathrm{fmol} / \mathrm{embryo} / \mathrm{h}$.

\section{Glutamine efflux (or exchange)}

One-cell embryos were flushed from in vivo and labelled in CZB medium without glucose for $1 \mathrm{~h}$. After washing, these embryos were allowed to efflux for $1 \mathrm{~h}$ in CZB medium containing different concentrations of unlabelled glutamine as described in 'Methods' (Table 3). In comparison with the no-efflux control which was processed immediately after labelling and washing, efflux in any medium variant demonstrated a $17-25 \%$ reduction in total glutamine found in the embryos. Effluxed samples did not differ from each other except in the case of $0.001 \mathrm{~mm}$ compared with $1.0 \mathrm{~mm}$-glutamine. As the glutamine concentration in the efflux medium increased, however, there was a slight decline in the amount of labelled glutamine found in the embryos.

Table 3. Efflux of glutamine from 1 -cell $\mathrm{CF} 1 \times$ B6SJLF1/J embryos after labelling with $5 \mu \mathrm{Ci}$ $\left[{ }^{3} \mathrm{H}\right]$ glutamine in CZB medium for $1 \mathrm{~h}$, washing, and effluxing in medium containing various amounts of unlabelled glutamine for $1 \mathrm{~h}$

\begin{tabular}{lc}
\hline $\begin{array}{l}\text { Glutamine conc. during } \\
\text { efflux (mM) }\end{array}$ & $\begin{array}{c}\text { Glutamine remaining } \\
\text { after efflux } \\
\text { (fmol/embryo/h) }\end{array}$ \\
\hline No efflux control & $161 \cdot 82 \pm 7.81^{\mathrm{a}}$ \\
0.00 & $132.68 \pm 6.79$ \\
0.001 & $134 \cdot 75 \pm 4 \cdot 16^{\mathrm{b}}$ \\
0.01 & $130 \cdot 50 \pm 6.01$ \\
$0 \cdot 10$ & $124 \cdot 73 \pm 4 \cdot 04$ \\
1.00 & $121 \cdot 11 \pm 4 \cdot 11^{\mathrm{b}}$ \\
\hline $\begin{array}{l}\text { Data represent glutamine remaining per embryo after } \\
\text { efflux from } 4 \text { replicate experiments } \pm \text { s.e.m. }\end{array}$ \\
aignificantly different from all other samples by \\
Student's $t$ test, $P \leqslant 0.03$. \\
'Significantly different from each other by Student's $t$ \\
test, $P=0.05$.
\end{tabular}

\section{Glutamine utilization to generate $\mathrm{CO}_{2}$}

Embryos isolated from in vivo showed a significant increase in the amount of glutamine utilized to generate $\mathrm{CO}_{2}$ between the 1-cell and 2-cell stage, a significant decline from the 2-cell stage to the 8-cell stage and another increase from the 8-cell stage to the blastocyst stage (Table 4). However, the percentage total glutamine uptake which was used to generate $\mathrm{CO}_{2}$ was $40 \%$ for 1 -cells, $70 \%$ for 2-cells and $20 \%$ for both 8 -cells and blastocysts. The presence of glucose in the labelling 
medium significantly decreased the amount of glutamine conversion to $\mathrm{CO}_{2}$ at the 8-cell stage but not at the blastocyst stage. The effect of glucose was not tested at the 1- and 2-cell stages.

When cultured embryos were used for measurements of glutamine utilization to generate $\mathrm{CO}_{2}$, there was a significantly steady increase in utilization from Day 2 through Day 4 in CZB medium without glucose (Table 4). Blastocysts were not tested in this medium as none developed in vitro during the course of these experiments. There seems to be some seasonal variation in the ability of these embryos to develop in culture to the blastocyst stage in the absence of a Day-3 glucose injection (C. A. Ziomek, C. L. Chatot, J. Lewis-Williams \& I. Torres, unpublished data). Embryos which developed in CZB medium with a Day-3 glucose injection gave significantly reduced glutamine utilization at the morula stage compared with CZB medium alone. A significant decline in glutamine utilization in CZB medium with glucose occurred between the morula and blastocyst stages. The percentage of total glutamine taken up per $\mathrm{h}$ which was utilized to generate $\mathrm{CO}_{2}$ in cultured embryos was $<20 \%$ in all cases.

Table 4. Glutamine utilization to generate $\mathrm{CO}_{2}$ by in-vivo and in-vitro raised embryos incubated in CZB medium with and without glucose containing $1 \mathrm{~mm}-\left[{ }^{14} \mathrm{C}\right]$ glutamine for $4 \mathrm{~h}$ at $37^{\circ} \mathrm{C}$

\begin{tabular}{|c|c|c|c|c|c|c|c|}
\hline \multicolumn{3}{|c|}{ In vivo } & \multicolumn{4}{|c|}{ In vitro } & \multirow{2}{*}{$\begin{array}{c}\text { In-vitro/ } \\
\text { in-vivo ratio } \\
\text { (in-vivo stage) }\end{array}$} \\
\hline $\begin{array}{l}\text { Embryo } \\
\text { stage }\end{array}$ & $\mathbf{N}$ & $\begin{array}{l}\text { Glutamine utilized } \\
\text { (fmol/embryo/h) }\end{array}$ & $\begin{array}{l}\text { Day of } \\
\text { culture }\end{array}$ & Stage & $\mathbf{N}$ & $\begin{array}{l}\text { Glutamine utilized } \\
\text { (fmol/embryo/h) }\end{array}$ & \\
\hline$C Z B$ & & & $C Z B$ & & & & \\
\hline 1-cell & 9 & $74 \cdot 18 \pm 6 \cdot 07^{\mathrm{a}}$ & & & & & \\
\hline 2-cell & 10 & $103.89 \pm 5 \cdot 34^{\mathrm{a}, \mathrm{b}}$ & D2 & 2-cell & 10 & $47 \cdot 48 \pm 3 \cdot 27^{r}$ & $0.46(2-C)$ \\
\hline 8-cell & 10 & $80 \cdot 50 \pm 5.65^{b, c, d}$ & D3 & 4-cell & 10 & $63.68 \pm 4.95^{\mathrm{f}, \mathrm{g}}$ & $0.79(8-\mathrm{C})$ \\
\hline Blastocyst & 10 & $164.93 \pm 10.81^{c}$ & D4 & Morula & 10 & $107.61 \pm 9.96^{\mathrm{g} \cdot \mathrm{h}}$ & $1.33(8-C)$ \\
\hline$C Z B+$ glucose & & & $C Z B$ & Day $3+g l t$ & & & \\
\hline 8-cell & 5 & $63 \cdot 44+2 \cdot 25^{\mathrm{d}, \mathrm{e}}$ & D4 & Morula & 9 & $72 \cdot 08+7 \cdot 14^{\mathrm{h} . \mathrm{i}}$ & $1 \cdot 14(8-C)$ \\
\hline Blastocyst & 5 & $145 \cdot 28 \pm 12 \cdot 52^{e}$ & D5 & Blastocyst & 10 & $50 \cdot 17 \pm 3 \cdot 25^{\mathrm{i}}$ & $0.37(\mathrm{Bl})$ \\
\hline
\end{tabular}

Values are mean \pm s.e.m. for the number of replicates $(N)$ indicated; each replicate contained 3 embryos. CZB $\rightarrow$ Day

$3+$ glucose, embryos were grown in CZB medium for Days 1 and 2 of culture, on Day 3 at $48 \mathrm{~h}$ glucose was injected into the culture as described in 'Methods'.

a,b,c,d,e,f,g,h,i, Like pairs are significantly different from each other at $P \leqslant 0.01(\mathrm{~b}, \mathrm{~d}, \mathrm{f}, \mathrm{h}, \mathrm{i})$ and $P \leqslant 0.005(\mathrm{a}, \mathrm{c}, \mathrm{e}, \mathrm{g})$.

Embryos at the 2-cell, 4-8-cell and blastocyst stages utilized significantly less glutamine when raised in vitro than their in-vivo raised counterparts ( $P \leqslant 0.03$ in all cases). At the morula stage, in the presence and absence of glucose, glutamine utilization was slightly greater for in-vitro than for in-vivo raised embryos (Table 4).

\section{Discussion}

The present experiments were done to gain a better understanding of the effects of CZB medium on glutamine uptake and utilization. The results clearly show effects of the medium upon both parameters. The data presented here confirm the beneficial effect of $1 \mathrm{~mm}$-glutamine and extend the dose response to lower concentrations $(0.5 \mathrm{~mm}$ and $0.1 \mathrm{~mm})$ which proved to be suboptimal. Glutamine was taken up by embryos from the unfertilized egg stage to the blastocyst stage both when embryos were flushed immediately from in vivo or were cultured in vitro in CZB medium. In 1-cell embryos raised in vivo, total glutamine uptake into the embryo increased proportionately with the amount of glutamine in the medium (up to $10 \mathrm{~mm}$ ), possibly indicating a diffusional uptake mechanism. Glutamine uptake was constant at the unfertilized egg and 1-cell stages and increased rapidly at the 8-cell, morula and blastocyst stages. These results are consistent with observations on the uptake of several other amino acids, in particular, methionine $_{,}$lysine, alanine, $_{,}$phenylalanine, $57 \mathrm{AM}$ 
glutamic acid and leucine, by preimplantation stage mouse embryos (Monesi \& Salfi, 1967; Epstein \& Smith, 1973; Borland \& Tasca, 1974, 1975; Kaye et al., 1982; Keefer \& Tasca, 1984; Van Winkle, 1988). The present observation of a decline in glutamine uptake at the 2-cell stage before a rapid increase in accumulation at the 8-cell stage is consistent with the pattern of leucine uptake described by Monesi \& Salfi (1967) and Epstein \& Smith (1973). Embryos cultured and labelled in the presence of $1 \mathrm{~mm}$-glutamine, although following the same pattern of uptake, accumulated 2-3 times more glutamine than did in-vivo raised embryos at each of the stages examined except the blastocyst stage. The increase in the amount of glutamine uptake in embryos raised in vitro compared with those raised in vivo must be a result of the culture medium. This result may reflect differences in the availability of glutamine in the oviduct and uterus compared with the cultured medium. Schultz et al. (1981) have determined the glutamine pool size for CFLP mouse eggs, 8-cell embryos and blastocysts to be $94 \pm 22,366 \pm 27$ and $348 \pm 108 \mathrm{fmol} / \mathrm{embryo}$, respectively. In the present study, the amount of glutamine accumulated at each embryo stage represents more than the estimated glutamine pool sizes for CFLP mouse embryos.

In cultured embryos, the addition of glucose to the culture and labelling medium caused significant increases in glutamine uptake at the 8-cell-morula and blastocyst stages when $1 \mathrm{~mm}$-glutamine are present during labelling and at the blastocyst stage when $1 \mathrm{~mm}$-glutamine was absent during labelling. Glucose addition had no effect on uptake in in-vivo raised embryos until the blastocyst stage when embryos were labelled in the presence of non-radioactive glutamine, at which time glutamine uptake declined. This is in contrast to the results of Gardner et al. (1989) who, using a non-invasive ultramicrofluorometric method to measure net glutamine uptake, demonstrated a significant decline in glutamine uptake in an M2 based medium by 1-, 2- and 8-cell CF1 embryos upon the addition of pyruvate, lactate and glucose. These observed differences in uptake in these two studies may reflect differences in medium composition or variations in the CF1 females (which were obtained from different suppliers). It is also possible that the decline in glutamine uptake observed by Gardner et al. (1989) was not due primarily to the glucose addition but to the addition of lactate and pyruvate, two energy sources known to be used by the mouse embryo. These energy substrates were present in CZB medium throughout the present study.

In the presence of $1 \mathrm{~mm}$-glutamine, $75 \%$ of the radiolabelled glutamine was retained by the embryo with an efflux or exchange of $25 \%$ with the surrounding medium during $1 \mathrm{~h}$. Whether this loss represents only glutamine or one or more of its many soluble metabolites is not known. It is evident that external glutamine neither retards nor stimulates the efflux (or exchange) of glutamine from the internal pool of the embryo, since the optimum concentration of glutamine for embryo culture allowed the greatest amount of efflux (or exchange), while the lowest efflux occurred in the absence of external glutamine. This latter result suggests that glutamine and/or its metabolites diffuse slowly across the embryo cell membrane. This result is in agreement with those of Kaye $e t$ al. (1982) who demonstrated increased efflux of $\left[{ }^{35}\right.$ S $]$ methionine from preloaded embryos (unfertilized egg to morula stages) in medium with increasing concentrations of non-radioactive methionine. However, the amount of methionine effluxed, which was $60-80 \%$ of initial uptake, was greater than that observed here for glutamine.

TCA precipitation of the embryo extracts revealed that $92-98 \%$ of the total accumulated glutamine was found in the TCA-soluble fraction suggesting that very little glutamine was utilized for protein synthesis during preimplantation stages for both in-vivo and in-vitro raised embryos. This result agrees with the findings of Brinster (1971) who showed that, in addition to glutamine being accumulated by the 1-2-cell Swiss mouse embryo better than a group of 10 other amino acids, $>90 \%$ TCA-precipitable counts at these stages was in the acid-soluble fraction. Reitzer et al. (1979) also demonstrated that $<2 \%$ of the glutamine utilized by HeLa cells was incorporated into protein.

Finally, it is clear that glutamine can be utilized as an energy substrate by all preimplantation stage embryos by oxidation to $\mathrm{CO}_{2}$ through the TCA cycle. In embryos raised in vivo, the percentage of total $\left[{ }^{14} \mathrm{C}\right]$ glutamine utilized to generate $\mathrm{CO}_{2}$ ranged from $70 \%$ at the 2-cell stage to $20 \%$ at 
the 8-cell and blastocyst stages. In HeLa cells in culture, which prefer glutamine over glucose, fructose or galactose as an energy source (Reitzer et al., 1979), 35\% of the glutamine was converted to $\mathrm{CO}_{2}, 13 \%$ was detected as lactate and $18-25 \%$ was incorporated into macromolecules. A similar effect was observed for human diploid fibroblasts (Zielke et al., 1976, 1980) and L929 mouse cells (Lanks, 1987) for which the reported metabolic products of glutamine included lactate, pyruvate, citrate, malate, glutamic acid and aspartic acid. In cultured rat thymocytes, Brand (1985) detected $32 \%$ carbon- 14 from glutamine in $\mathrm{CO}_{2}$ and $61 \%$ in aspartic acid. These results suggest that cells in culture use glutamine as an energy substrate through the TCA cycle and oxidation to $\mathrm{CO}_{2}$. The current data support a similar role for glutamine in the preimplantation mouse embryo.

In embryos raised in vivo, the addition of glucose did not affect the generation of ${ }^{14} \mathrm{CO}_{2}$ at any stage with the exception of the 8-cell stage at which it significantly decreased the absolute amount of $\left[{ }^{14} \mathrm{C}\right]$ glutamine used to generate $\mathrm{CO}_{2}$. In human diploid fibroblasts and rat thymocytes in culture, Sumbilla et al. (1981), Zielke et al. (1984) and Brand (1985) described a reciprocal regulation of utilization between glutamine and glucose. Glucose inhibited the oxidation of glutamine by as much as $85 \%$, whereas other energy substrates, such as ketone bodies and fatty acids, had no effect (Sumbilla et al., 1981). Overall, in cells in culture, rates of glutamine oxidation are a function of the concentrations of glutamine and glucose, as well as the levels of the enzyme glutaminase, which increases in rapidly proliferating cells (Sevdalian et al., 1980; Brand, 1985).

In cultured embryos, there was a steady increase in the generation of $\mathrm{CO}_{2}$ from $\left[{ }^{14} \mathrm{C}\right]$ glutamine with further development. The percentage of total glutamine taken up by cultured embryos that was used for $\mathrm{CO}_{2}$ production was less than $20 \%$ in all cases. This reduced level, compared with invivo raised embryos, was not due to a severe decline in the absolute amount of glutamine utilization but was the result of the increased uptake of glutamine in cultured embryos. The presence of glucose in the culture medium caused a significant decrease in the utilization of glutamine at the 8cell to morula stage. The further decline in glutamine utilization at the blastocyst stage may represent the need to shuttle glutamine to other synthetic systems in vitro as cell numbers increase and the embryo requires increased synthesis of nucleic acids and proteins. Cultured embryos may also behave like other cells in culture where the presence of glucose causes a significant decline in glutamine utilization.

It is apparent from these results that glutamine can be utilized by preimplantation mouse embryos as an energy substrate in addition to pyruvate and lactate. Both pyruvate and lactate have been shown to be metabolized through the TCA cycle to generate $\mathrm{CO}_{2}$ in vivo (Wales \& Whittingham, 1967, 1973) and in vitro (Brinster, 1969; Wales \& Whittingham, 1970). Perhaps the addition of glutamine to the culture medium provides an additional boost in flux through the TCA cycle which is required for the generation of sufficient energy to develop in vitro beyond the 2-cell stage for strains which exhibit a developmental arrest in vitro at this stage, although other explanations are possible.

The present study has shown that glutamine which enhances the development of 1-cell $\mathrm{CF} 1 \times \mathrm{B} 6 \mathrm{SJLF} 1 / \mathrm{J}$ embryos beyond the 2 -cell stage in vitro has an optimum effective concentration of $1 \mathrm{~mm}$ and that embryos are not significantly affected by pyrrolglutamic acid, a potentially toxic degradation product of glutamine. Glutamine is taken up by embryos raised in vivo as well as by cultured embryos of all preimplantation stages and can be utilized by the embryo as an energy substrate for the generation of $\mathrm{CO}_{2}$. The addition of glucose to cultures of 1-cell embryos at Day 3 of culture facilitates increased development of embryos to the blastocyst stage as well as a stimulation of total glutamine uptake although the amount of glutamine utilized by cultured embryos to generate $\mathrm{CO}_{2}$ at later stages declines. Further studies should lead to a clearer understanding of the roles of glutamine and glucose during preimplantation development.

We thank Jennifer Lewis-Williams and Ioannis Torres-Berrios for expert technical assistance with the mouse embryo culture. This work was done as part of the National Cooperative Program on Non-Human In Vitro Fertilization and Preimplantation Development and was funded by the 
National Institute of Child Health and Human Development, NIH, through cooperative agreement HD21942 (C.A.Z.) and National Cancer Institute, NIH, grant P030CA12708 (C.A.Z.).

\section{References}

Abramczuk, J., Solter, D. \& Koprowski, H. (1977) The beneficial effect of EDTA on development of mouse one-cell embryos in chemically defined medium. Devl Biol. 61, 378-383.

Bae, I.H. \& Foote, R.H. (1975) Carbohydrate and amino acid requirements and ammonia production of rabbit follicular oocytes matured in vitro. Expl Cell Res. 91, 113-118.

Bavister, B.D., Leibfried, M.L. \& Leiberman, G. (1983) Development of preimplantation embryos of the golden hamster in a defined culture medium. Biol. Reprod. 28, 235-247.

Biggers, J.D., Whittingham, D.G. \& Donahue, R.P. (1967) The pattern of energy metabolism in the mouse oocyte and zygote. Proc. natn. Acad. Sci. USA $58,560-567$.

Blomback, B. (1967) Derivatives of glutamine in peptides. In Methods in Enzymology, Vol. 11, pp. 398-411. Ed. C. H. W. Hirs. Academic Press, New York.

Borland, R.M. \& Tasca, R.J. (1974) Activation of a $\mathrm{Na}^{+}-$ dependent amino acid transport system in preimplantation mouse embryos. Devl Biol. 30, 169-182.

Borland, R.M. \& Tasca, R.J. (1975) $\mathrm{Na}^{+}$dependent amino acid transport in preimplantation mouse embryos. II Metabolic inhibitors and nature of the cation requirement. Devl Biol. 46, 192-201.

Brand, K. (1985) Glutamine and glucose metabolism during thymocyte proliferation. Biochem. J. 228, 353-361.

Brinster, R.L. (1969) Incorporation of carbon from glucose and pyruvate into the preimplantation mouse embryo. Expl Cell Res. 58, 153-158.

Brinster, R.L. (1971) Uptake and incorporation of amino acids by the preimplantation mouse embryo. $J$. Reprod. Fert. 27, 329-338.

Carney, E.W. \& Bavister, B.D. (1987) Stimulatory and inhibitory effects of amino acids on development of hamster eight-cell embryos in vitro. J. In Vitro Fert. Embryo Transfer 4, 162-167.

Chatot, C.L., Ziomek, C.A., Bavister, B.D., Lewis, J.L. \& Torres, I. (1989) An improved culture medium supports development of random-bred 1-cell mouse embryos in vitro. J. Reprod. Fert. 86, 679-688.

Chatot, C.L., Lewis, J.L., Torres, I. \& Ziomek, C.A. (1990) Development of 1-cell embryos from different strains of mice in CZB medium. Biol. Reprod. 42 (in press).

Cross, P.C. \& Brinster, R.L. (1973) The sensitivity of one-cell mouse embryos to pyruvate and lactate. Expl Cell Res. 77, 57-62.

Eagle, H., Oyama, V.I., Levy, M., Horton, C.L. \& Fleischman, R. (1955) The growth response of mammakian cells in tissue culture to L-glutamine and L-glutamic acid. J. biol. Chem. 218, 607-616.

Epstein, C.J. \& Smith, S.A. (1973) Amino acid uptake and protein synthesis in preimplantation mouse embryos. Devl Biol. 33, 171-184.

Gardner, D.K., Clarke, R.N., Lechene, C.P. \& Biggers, J.D. (1989) Development of a non-invasive ultra- microfluorometric method for measuring net uptake of glutamine by single preimplantation mouse embryos. Gamete Res. 24, 427-438.

Gwatkin, R.B.L. \& Haidri, A.A. (1973) Requirements for the maturation of hamster oocytes in vitro. Expl Cell Res. 76, 1-7.

Kaufman, M.H. \& Sachs, L. (1976) Complete preimplantation development in culture of parthenogenetic mouse embryos. J. Embryol. exp. Morph. 35, 179-190.

Kaye, P.L., Shultz, G.A., Johnson, M.H., Pratt, H.P.M. \& Church, R.B. (1982) Amino acid transport and exchange in preimplantation mouse embryos. $J$. Reprod. Fert. 65, 367-380.

Keefer, C.L. \& Tasca, R.J. (1984) Modulation of amino acid transport in preimplantation mouse embryos by low concentrations of non-ionic and zwitterionic detergents. J. Reprod. Fert. 70, 399-407.

Lanks, K.W. (1987) End products of glucose and glutamine metabolism by $\mathrm{L} 929$ cells. J. biol. Chem. 262, 10093-10097.

Loutradis, D., John, D. \& Kiessling, A.A. (1987) Hypoxanthine causes a 2-cell block in random-bred mouse embryos. Biol. Reprod. 37, 311-316.

Monesi, V. \& Salfi, V. (1967) Macromolecular synthesis during early development in the mouse embryo. Expl Cell Res. 46, 632-635.

Nomura, T. \& Rubin, H. (1988) Quantitative studies of amino acid and growth factor requirements of transformed and non-transformed cells in high concentrations of serum or lymph. In Vitro Cell Dev. Biol. 24, 878-884.

O'Fallon, J.V. \& Wright, R.W., Jr (1986) Quantitative determination of the pentose phosphate pathway in preimplantation mouse embryos. Biol. Reprod. 34, 58-64.

Petters, R.M., Johnson, B.H., Reed, M.L. \& Archibong, A.E. (1990) Glucose, glutamine and inorganic phosphate in early development of the pig embryo in vitro. J. Reprod. Fert. 89, 269-275.

Quinn, P. \& Harlow, G.M. (1978) The effect of oxygen on the development of preimplantation mouse embryos in vitro. J. exp. Zool. 206, 73-80.

Rieger, D. \& Guay, P. (1988) Measurement of the metabolism of energy substrates in individual bovine blastocysts. J. Reprod. Fert. 83, 585-591.

Reitzer, L.J., Wice, B.M. \& Kennell, D. (1979) Evidence that glutamine, not sugar, is the major energy source for cultured Hela cells. J. biol. Chem. 254, 2669-2676.

Salzman, N.P., Eagle, H. \& Sebring, E.D. (1958) The utilization of glutamine, glutamic acid, and ammonia for the biosynthesis of nucleic acid bases in mammalian cell cultures. J. biol. Chem. 230, 1001-1012.

Schini, S.A. \& Bavister, B.D. (1988) Two cell block to development of cultured hamster embryos is caused by phosphate and glucose. Biol. Reprod. 39, 1183-1192.

Schultz, G.A., Kaye, P.L., McKay, D.J. \& Johnson, M.H. (1981) Endogenous amine acid pool 6 sizes $_{3}$ in p $_{0}: 54: 57 \mathrm{Am}$ 
mouse eggs and preimplantation embryos. J. Reprod. Fert. 61, 387-393.

Schumacher, A. \& Fischer, B. (1988) Influence of visible light and room temperature on cell proliferation in preimplantation rabbit embryos. J. Reprod. Fert. 84, 197-204.

Sevdalian, D.A., Ozand, P.T. \& Zielke, H.R. (1980) Increase in glutaminase activity during the growth cycle of cultured human diploid fibroblasts. Enzyme 25, 142-144.

Sokal, R.R. \& Rohlf, F.J. (1981) Biometry, pp. 427-428. W.H. Freeman and Co., New York.

Stryer, L. (1988) Biochemistry, pp.601-609. W.H. Freeman and Co., New York.

Sumbilla, C.M., Zielke, C.L., Reed, W.D., Ozand, P.T. \& Zielke, H.R. (1981) Comparison of the oxidation of glutamine, glucose, ketone bodies and fatty acids by human diploid fibroblasts. Biochim. Biophys. Acta 675, 301-304.

Tasca, R.J. \& Hillman, N. (1970) Effects of actinomycin $\mathrm{D}$ and cycloheximide on RNA and protein synthesis in cleavage stage mouse embryos. Nature, Lond. 225, $1022-1025$.

Van Winkle, L.J. (1988) Amino acid transport in developing animal oocytes and early conceptuses. Biochim. Biophys. Acta 947, 173-208.

Wales, R.G. \& Whittingham, D.G. (1967) A comparison of the uptake and utilization of lactate and pyruvate by one- and two-cell mouse embryos. Biochim. Biophys. Acta 148, 703-712.
Wales, R.G. \& Whittingham, D.G. (1970) Metabolism of specifically labelled pyruvate by mouse embryos during culture from the two-cell stage to the blastocyst. Aust. J. biol. Sci. 23, 877-887.

Wales, R.G. \& Whittingham, D.G. (1973) The metabolism of specifically labelled lactate and pyruvate by two-cell mouse embryos. J. Reprod. Fert. 33, 207-222.

Whitten, W.K. \& Biggers, J.D. (1968) Complete development in vitro of the preimplantation stages of the mouse in a simple chemically defined medium. $J$. Reprod. Fert. 17, 399401.

Whittingham, D.G. \& Biggers, J.D. (1967) Fallopian tube and early cleavage in the mouse. Nature, Lond. 213, 942 .

Zielke, H.R., Ozand, P.T., Tildon, J.T., Sevdalian, D.A. \& Cornblath, M. (1976) Growth of human diploid fibroblasts in the absence of glucose utilization. Proc. natn. Acad. Sci. USA 73, $4110-4114$.

Zielke, H.R., Sumbilla, C.M., Sevdalian, D.A., Hawkins, R.L.\& Ozand, P.T. (1980) Lactate: A major product of glutamine metabolism by human diploid fibroblasts. J. Cell Physiol. 104, 433-441.

Zielke, H.R., Zielke, C.L. \& Ozand, P.T. (1984) Glutamine: a major energy source for cultured mammalian cells. Fedn Proc. Fedn Am. Socs exp. Biol. 43, $121-125$. 